\title{
A NEW ARIETELLID COPEPOD (CRUSTACEA): PILARELLA LONGICORNIS, GEN. N., SP. N., FROM THE BRAZILIAN CONTINENTAL SHELF
}

MARIA PALOMA JIMENEZ ALVAREZ

\section{ABSTRACT}

Pilarella longicornis gen. n., sp. n. (Copepoda-Arietellidae) collected over the bottom of the Brazilian continental shelf is described and its taxonomic position is discussed.

\section{INTRODUCTION}

On redefining the Arietellidae Campaner (1977) commented on the large number of new genera and species of copepods which he found in samples collected over the bottom of the Brazilian continental shelf. He started the study of these copepods adding new species to the Aetideidae, Phaennidae, Scolecithricidae and Arietellidae (Campaner, 1974, 1976, 1978a and b, 1979).

This paper results from the continuation of that work with the same series of samples. Twenty eight more samples were analyzed (Alvarez, 1981) and several new species found, among which a new Arietellid. Once more a rich fauna, as yet little known, was registered near to the bottom of the sea.

\section{MATERIAL}

Five adult females were analyzed from a sample taken at $135 \mathrm{~m}$ depth, over the bottom of the Brazilian continental shelf $\left(28^{\circ} 36^{\prime} \mathrm{S}-47^{\circ} 55^{\prime} \mathrm{W}\right)$ at $21: 29$ o'clock on the $22^{\text {nd }}$ June 1970 . The plankton net used $(0.67 \mathrm{~mm}$ mesh aperture) was adapted to a special MBT dredge devised by Dr. Plínio Soares Moreira from the Instituto Oceanográfico of the University of São Paulo.

The holotype and a paratype were placed in the Zoology Museum of the University of São Paulo numbered 5255 and 5256 respectively. Three females were deposited in the Copepod Collection of the Department of Zoology of the Instituto de Biociências of the same University numbered 186.

Pilarella, gen. n.

\section{Definition:}

Female - Cephalosome not fused to the first metasomal segment. Fourth and fifth metasomal segments fused. Rostrum relatively wide, long and with two long tapering filaments, very thin distally. Urosome four-segmented; anal segment short. Caudal rami very long, the length about half that of the urosome. Antennae 1 asymmetrical, both with 21 joints, the left longer, and reaching the furcal rami when fully distended. Maxilla 1 with 5 spiniform setae on its first internal lobe, 1 setose seta on the $2^{\text {nd }}$ internal lobe; 2 setae on the endopod, 5 setae on the $1^{\text {st }}$ external lobe and 3 terminal setae on the exopod. The other buccal appendages and the four first pairs of legs similar to those of the genus Metacalanus. Fifth pair of legs symmetrical and 3-jointed; $2^{\text {nd }}$ joint globose with an external, short, distal seta and one, internal, long seta; $3^{\text {rd }}$ joint with one short lateral, external seta, one short seta and one long seta; endopod absent.

Male - unknown.

Type-species - Pilarella longicornis, sp. n.

Departamento de Zoologia, Instituto de Biociências, Universidade de São Paulo. 


\section{Pilarella longicornis, sp. n.}

Description of adult female: (Figs. 1-19).

Length along the mid dorsal line of the holotype $=1.73 \mathrm{~mm}$ (varying from 1.53 to $1.73 \mathrm{~mm}$; average $1.60 \mathrm{~mm}$ ). Cephalosome (Figs. 1 and 2) not fused with the first segment of the metasome. Rostrum (Fig. 2) long, with two long tapering filaments. Fourth and fifth metasomal segments fused and rounded at the posterior margin in lateral view.

Proportion of prosome to urosome lengths $=63.37$. Proportion between cephalosome length and lengths of metasomal segments 52:10:10:10:18 = 100. Urosome four-segmented; the genital segment (Fig. 4) largest, with two lateral bulges. Anal segment reduced, with a sort of operculum (Fig. 5 and 6) ornamented with a series of very short marginal setules. Caudal rami with five terminal long setae each (their length more or less equal to half the total length of the united urosome segments). Proportion between length of urosome segments and caudal rami length 27.0:18.9:10.8:9.5:33.8 $=100$.

Antennae 1 asymmetrical, both with 21 joints. Left (Fig. 7) longer, reaching caudal rami when fully distended. Right antenna 1 (Fig. 8) with joints $2^{\text {nd }}$ to $10^{\text {th }}$ very short. Proportions of joint-lengths of righ antenna 1: 117: $31: 16: 16: 16: 8: 8: 11: 8: 15: 31: 50: 60: 70: 82: 89: 97: 101: 50: 70: 50=1.000$. Proportions between lengths of the left antenna 1 joints: $79: 36: 32: 47: 54: 50: 18: 14: 14: 18: 32$ : $72: 75: 75: 72: 65: 54: 68: 39: 36: 50=1.000$.

Antenna 2 (Fig. 9) exopod slightly longer than endopod; exopod with 1 and 7 setae respectively on $1^{\text {st }}$ and $2^{\text {nd }}$ joints.

Mandible palp (Fig. 10) short with long setae; endopod absent. Gnathobase (Fig. 11) with 4 strong teeth (the most dorsally situated tricuspid) and some setules at the base of dorsal tooth.

Maxilla 1 (Fig. 12) with 5 spine-like setae on its first internal lobe, one setose seta on the $2^{\text {nd }}$ internal lobe, two setae on the reduced endopod, 5 setae on the first external lobe, and 3 terminal very long setae on the exopod.

Maxilla 2 (Fig. 13) with 2 strong short setae on each of the two lobes of the first and second basipods. Endopod 4-jointed with a strong spine-like spinose seta on the first joint and in the three other joints respectively 4,2 , and 2 long, strong setae provided with two series of spinules each.

Maxilliped (Fig. 14) well developed. Endopod 5-jointed with respectively $4,4,3,3$, and 2 setae, some of which with spinules.

Legs (Figs. 15 to 18 ) with 3 -jointed endopods and exopods. Exopods of $2^{\text {nd }}$, $3^{\text {rd }}$, and $4^{\text {th }}$ legs with a terminal large spine, with serrated external margin, and marginal smaller spines with internal serrated margins, externally. Fourth pair of legs differs from $2^{\text {nd }}$ and $3^{\text {rd }}$ in the seta on $1^{\text {st }}$ basipod which is short and thin, and, in the long terminal spine of the exopod, with its margin more finely serrated than in the preceding pairs of legs. Fifth pair of legs (Fig. 19) symmetrical and 3 -jointed; $2^{\text {nd }}$ joint globose with a distal external short seta and a long internal one; $3^{\text {rd }}$ joint with a short lateral external seta and distally a long and a short seta. Endopod absent.

Male unknown.

\section{DISCUSSION}

The genus Pilarella was established mostly based on the structure of the fifth pair of legs, the length and number of joints of the antennae 1 , the structure of the maxillule and the length of the furcal rami. These features separate this genus from the other genera of the Arietellidae, especially from Metacalanus with which it has the greatest affinity.

The genus Metacalanus Cleve, 1901 contained one only species (M. aurivilli) but Campaner (1984), on studying the taxonomy of the Arietellidae, found that Scottula inaequicornis Sars, 1902 was congeneric with the first species cited, based mostly on the structure of the male fifth pair of legs (identical in both species). Campaner (1984) came to the conclusion that the description of Scottula ambariakae Binet \& Dessier, 1968 (= M. aurivilli $)$ and the description of $M$. aurivilli by Greenwood (1978) confirmed the similarity between 


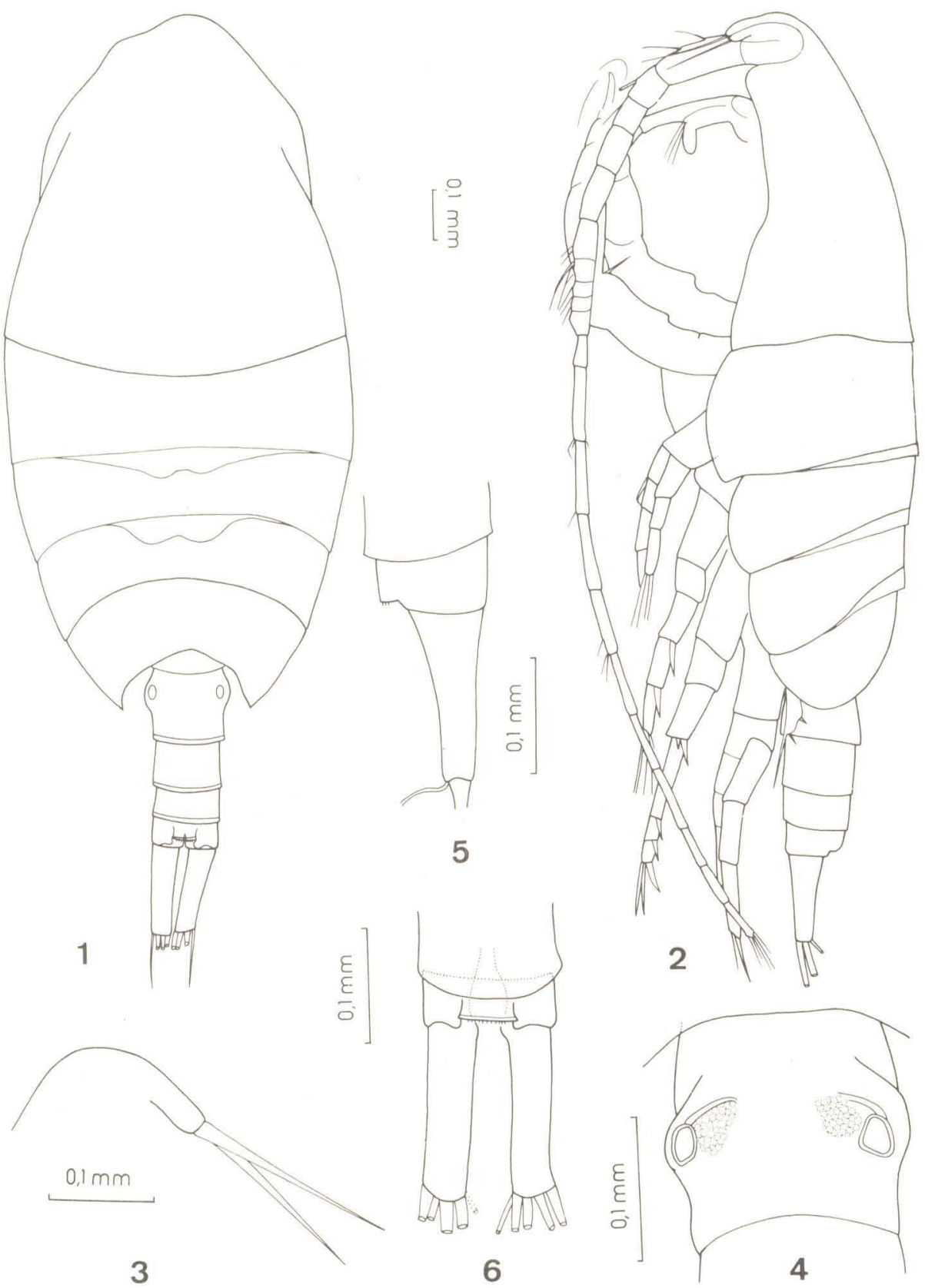

Pilarella longicornis, sp. n. female: Fig. 1 - Dorsal view; Fig. 2 - Lateral view; Fig. 3 - Rostrum, lateral; Fig. 4 - Genital segment of the urosome, ventral; Fig. 5 - Anal segment and caudal rami, lateral; Fig. 6 - Anal segment and caudal rami, dorsal. 

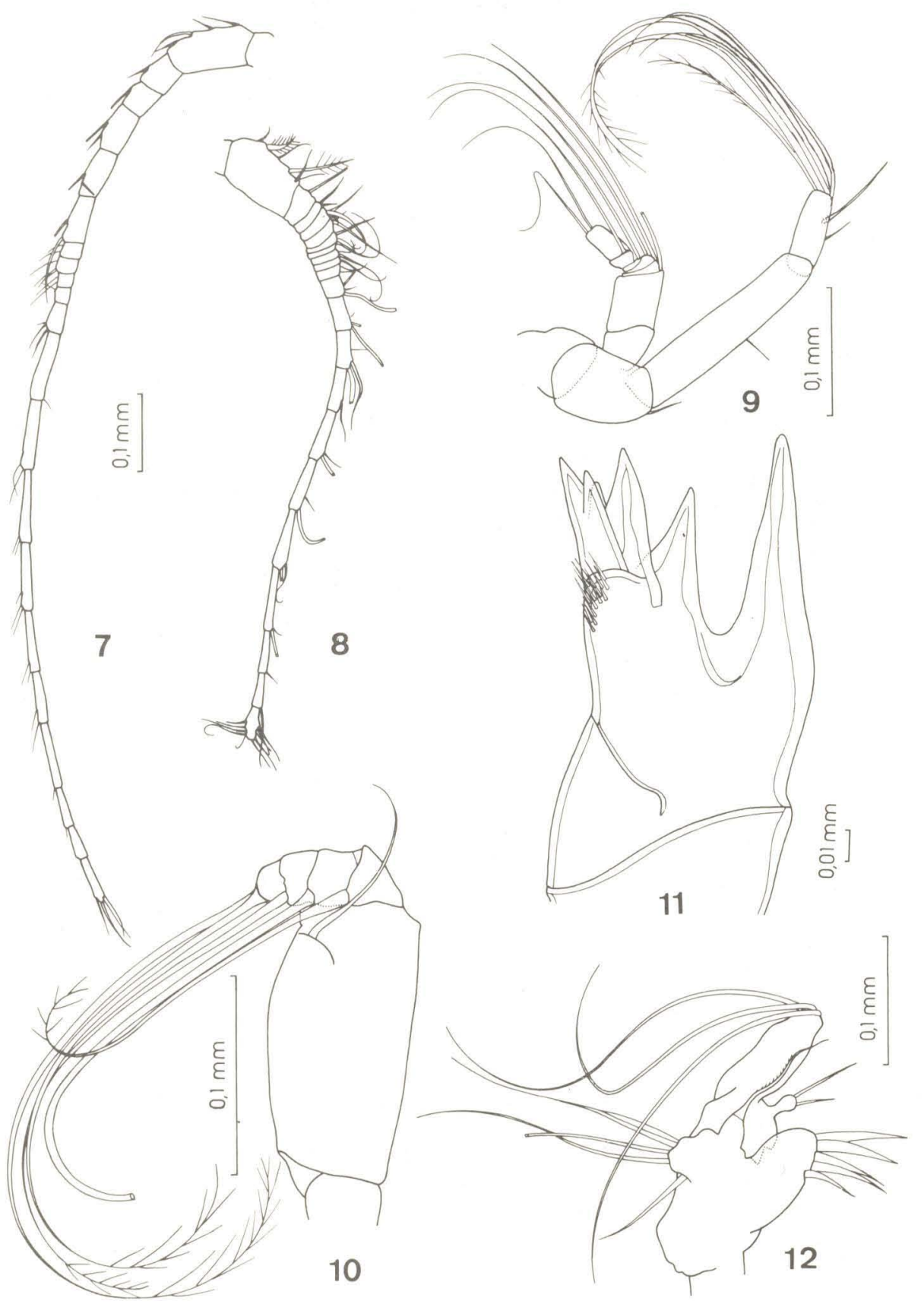

Pilarella longicornis, sp. n. female: Fig. 7 - Left antenna 1; Fig. 8 - Right antenna 1; Fig. 9 - Antenna 2; Fig. 10 - Mandibular palp; Fig. 11 Gnathobase of the mandible; Fig. 12 - Maxilla 1. 

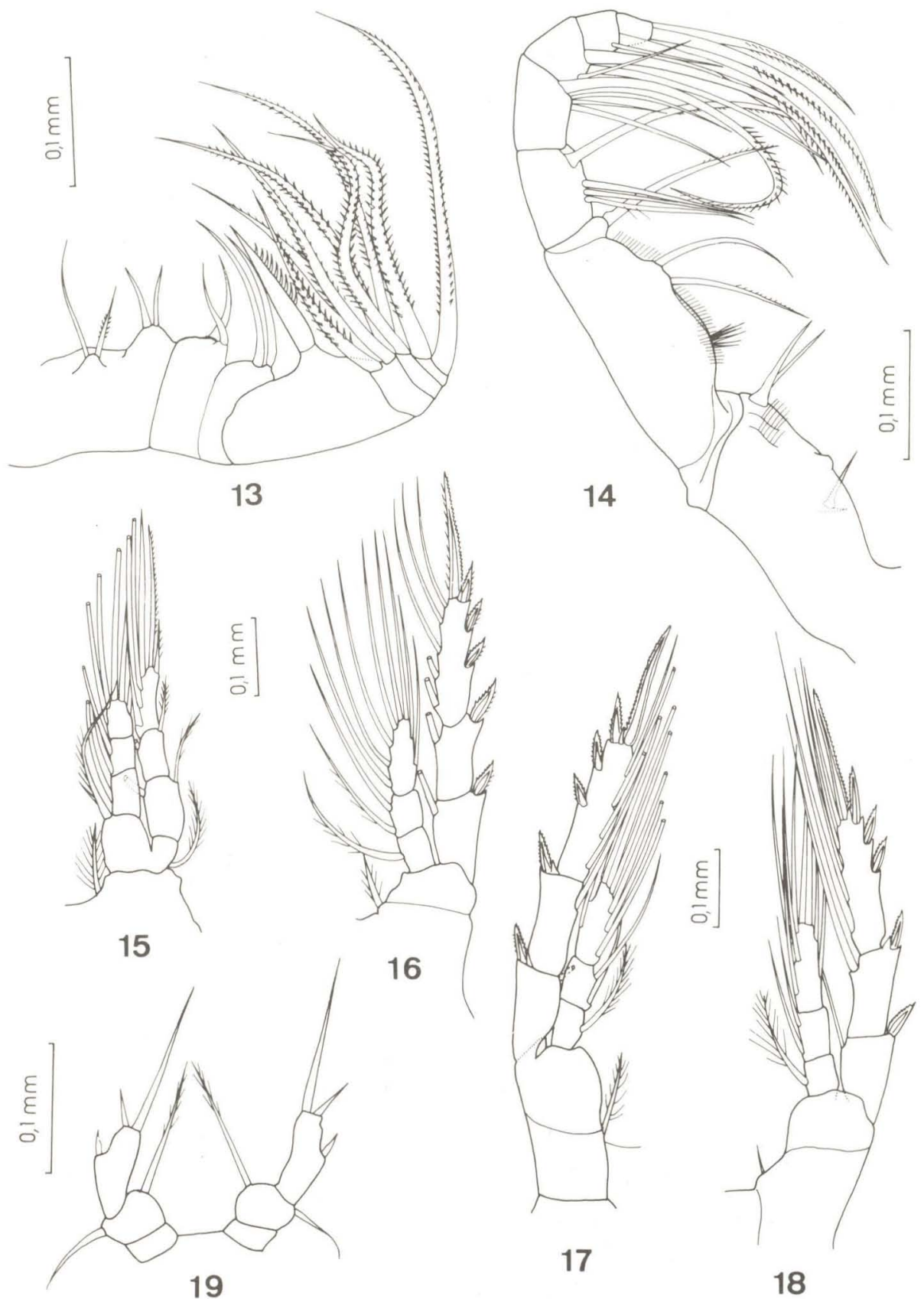

Pilarella longicornis, sp. n. female Fig. 13 - Maxilla 2; Fig. 14 - Maxilliped; Fig. 15 - First leg; Fig. 16 - Second leg; Fig. 17 - Third leg; Fig. 18 Fourth leg; Fig. 19 - Fifth leg. 
the two species even to the presence of an equal anal operculum. Ohtsuka (1984) described $M$. acutioperculum, the third species of the genus.

The genera discussed, Metacalanus and Pilarella, are similar as to the asymmetry of the antenna 1 and structure of the buccal appendages (excepting that of the maxilla 1) and legs. The genus Metacalanus differs in the number (from 16 to 20 ) of joints of the antenna 1, the right one having a smaller number of joints than the left one, and also because they are shorter than in the genus Pilarella; they do not reach the posterior margin of the metasome when fully distended. The furcal rami are also short and the maxilla 1 has a different number of setae which are differently distributed.

The fifth pair of legs of the female $M$. inaequicornis is very similar to the species here described, but it does not have the globose second joint.

Among the other genera of the Arietellidae family, Scutogerulus Bradford, 1969 is the second nearest of kin, considering the structure of the fifth pair of legs in the female, but there are considerable differences in the buccal appendages (especially in the antenna 2, maxilla 2 and maxilliped).

As occurred with Scottula inaequicornis, it is only when the male of Pilarella longicornis becomes known that the validity of this new genus shall be confirmed or not.

Etymology: The generic name was given in honor of my mother Maria Pilar Alvarez Brancal and the specific name from the latin longe = long and cornis $=$ horn, refers to the length of the antenna 1 .

\section{ACKNOWLEDGMENTS}

I am very grateful to Dr. T. K. S. Björnberg and Dr. A. F. Campaner for criticizing the manuscript. I also want to thank Dr. P. S. Moreira wo collected the material.

Financial support was provided by the Conselho Nacional de Desenvolvimento Científico e Tecnológico (Process number 105036-76).

\section{REFERENCES}

Alvarez, M. P. J., 1981. "New copepods (Crustacea) of the families Aetideidae, Phaennidae and Arietellidae collected off Brazilian coast”. São Paulo, USP, 127 p, D Sc Thesis, Zoology Dept., Inst. Biociências, Univers. S. Paulo, Brazil.

Binet, D. \& Dessier, A., 1968. Zooplankton de la region de Nozy - Bé. III. Premières donnés sur les copépodes. Cah. O. R. S. T. O. M., sér. Océanogr. 6(3-4): 3-26.

Bradford, J., 1969. New genera and species of benthic calanoid copepods from the New Zealand slope. N. Z. Jl. mar. freshwat. Res. 3(4): 473-505.

Campaner, A. F., 1974. "Planktobenthic copepods (Crustacea) from the Bra-

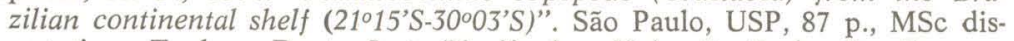
sertation, Zoology Dept., Inst. Biociências, Univ. S. Paulo, Brazil.

Campaner, A. F., 1976. "On some new planktobenthic Aetideidae and Phaennidae (Copepoda, Calanoida) from the Brazilian continental shelf $\left(23^{\circ}-25^{\circ} \mathrm{S}\right.$ and $\left.41^{\circ}-46^{\circ} \mathrm{W}\right)$. São Paulo, USP, 103 p., D Sc Thesis, Zoology Dept., Inst. Biociências, Univers. S. Paulo, Brazil.

Campaner, A. F., 1977. New definition of the Arietellidae (Copepoda, Calanoida), with the description of a new genus and species, and separation of the Phyllopidae fam. n. Ciênc. Cult., 29(7): 811-18.

Campaner, A. F., 1978a. On some plancktobentic Aetideidae and Phaennidae (Copepoda, Calanoida) from the Brazilian continental shelf. I. Aetideidae. Ciênc. Cult. 30(7): 863-76.

Campaner, A. F., 1978b. On some new planktobentic Aetidaeidae and Phaennidae (Copepoda, Calanoida) from the Brazilian continental shelf. II. Phaennidae. Ciên. Cult. 30(8): 966-82.

Campaner, A. F., 1979. On a new planktobenthic Scolecithricid copepod (Calanoida, Crustacea) from the Brazilian continental shelf. Bolm Zool USP. 4: $81-8$. 
Campaner, A. F., 1984. Some taxonomic problems within the Arietellidae (Copepoda, Calanoida). Crustaceana suppl. 7: 102-109.

Cleve, P. T., 1901. Plankton from the Indian Ocean and Malay Archipelago. K. Svenska Vetensk. Akad. Handl. 35(5): 1-58.

Greenvood, J. G., 1978. Calanoid Copepods of Moreton Bay (Queensland) III. Families Temoridae to Tortanidae, excluding Pontellidae. Proc. $R$. Soc. Qd. 89: 1-21.

Ohtsuka, S., 1984. Calanoid Copepods collected from the near bottom in Tanabe Bay on the Pacific Coast of the Middle Honshu, Japan. I. Arietellidae. Publ. Seto mar. Biol. Lab. 29(4-6): 359-365. 